\title{
PERFORMANCE OF DIFFERENT LEVELS OF NITROGEN AND PHOSPHORUS ON HERBAGE YIELD, NUTRIENT CONTENT AND UPTAKE OF RAIN FED PALMAROSA (CYMBOPOGAN MARTINI VAR. MOTIA)- A REVIEW
}

\author{
M. Jayalakshmi*, S.G. Wankhade and P. Mohan Rao \\ Dr.Panjab Rao Deshmukh Krish Vidyapeeth, \\ Akola-444 104, India
}

Received:17-08-2012

Accepted: 11-04-2013

\begin{abstract}
Cymbopogan martini var. Motia commonly known as Palmarosa or Rosha grass is a tall perennial tufted hedge native of most parts of sub-tropical India. Palmarosa oil has a sweet floral rose-like odour also has notes of rye bread, tea and clary sage. The oil is extensively used as perfumery raw material in soaps; floral rose-like perfumes; cosmetics preparations and in the manufacture of mosquito repellent products. It is used for flavoring tobacco products, foods and non-alcoholic beverages. The volatile oil is used as a remedy for lumbago, stiff joints, skin diseases and for bilious complaints .Considering the importance of this crop every efforts are being made to increase the oil production of the crop by using improved nutrient management practices.
\end{abstract}

Key words: Nutrient uptake, Palmarosa.

Cympogon martinii commonly known as Palmarosa or Rosha grass is a tall perennial tufted hedge native of most parts of sub tropical India. The species occurs in patches in open shrub forests in parts of Madhya Pradesh, Maharashtra and Andhra Pradesh where it is commercially collected and distilled for its oil. It is universally accepted that the use of chemical fertilizers is an integral part of the package of practices (like use of improved seeds, proper soil and water management, improved cultural practices, plant protection measures, post harvest o perations etc. However literature on nutrient management in palmarosa is lacking. Therefore, the requirement of nutrients should be worked out with prime consideration to soil test values and biological yield potential for specific locations. Hence a field experiment was carried out during 2007-2008 to study the effect of Nitrogen and Phosphorus on oil yeld of palmarosa. Very merge research work has been worked out on Palmarosa particularly on nutritional management therefore the literature available on other aromatic and medicinal crops is also reviewed and presented in this review under appropriate heads.
Effect of nitrogen on herbage yield of Palmarosa:Dutta and Paul (1976) stated that the $80 \mathrm{~kg} \mathrm{~N}$ level with $P$ and $\mathrm{K}$ each of $40 \mathrm{~kg}$ per hectare gave higher herbage yields than unfertilized but the yield differences between various nitrogen levels were found non significant in Palmorosa grass. The yield of green grass increases significantly with increase of the doses of $\mathrm{N}$ from 0 to $80 \mathrm{~kg} \mathrm{ha}^{-1}$. But at $\mathrm{N} 80 \mathrm{~kg}$ $\mathrm{ha}^{-1}$ dose, yield of grass decreases. The application of $60 \mathrm{~kg} \mathrm{~N}$ with $P$ and $K$ each $40 \mathrm{~kg} \mathrm{ha}^{-1}$ was found to increase the yield of herb and Palmarosa oil than the control.( Hazarika and Bora 1977)

Husain (1979) conducted an experiment to study economics of nitrogen fertilization in Java citronella. Nitrogen (total or fraction) was applied either as urea Straw-mud-ball of 10:1 C:N ratio or neem cake blended urea along with various combinations of spray and soil applications. Three doses of nitrogen $(100,125$ and $150 \mathrm{~kg} \mathrm{~N} / \mathrm{ha}$ ) were used. The data obtained for the first harvest indicated that three split applications of nitrogen starting from sprouting was better than three split applications starting from planting (usual practice) at all levels of nitrogen application. There was a reduction in the herb yield when nitrogen was applied as urea Straw-

\footnotetext{
*Corresponding authore's: e-mail: jayalakshmimitnala@ gmail.com
} 
mud-ball however herb yield increased on the application of neem cake blended urea. From series of an experiment conducted on lemon grass for more than a decade by Nair et al. (1979) suggested that application of $100 \mathrm{~kg} \mathrm{~N} \mathrm{ha}^{-1}$ was found to be beneficial than control.

High dose of nitrogen i.e. $120 \mathrm{~kg} \mathrm{~N} \mathrm{ha}^{-1} \mathrm{yr}^{-1}$ for good growth and yield of J ava citronella while $80 \mathrm{~kg} \mathrm{~N} \mathrm{ha}^{-1} \mathrm{yr}^{-1}$ suggested for the soil with high level of fertility. The application of $P$ and $K$ each of $40 \mathrm{~kg}$ ha-1 was found better results. (Virmani et al. 1979) A field investigation was carried out for 2 years on a red sandy loam soil in the semi-arid tropical climate of South India, to study the influence of different levels of farm yard manure (FYM) ( 0 and 15 t/ha per year) and fertilizer nitrogen $(0,40,80 \mathrm{~kg} \mathrm{~N} / \mathrm{ha}$ per year) on the biomass and essential oil yields of palmarosa (Cymbopogonmartinii (Roxb.) Wats. var. motia Burk., family, Poaceae) grown under rainfed condition. During the period of investigation, palmarosa gave seven harvests in 2 years with 23.6$37.2 \mathrm{t} / \mathrm{ha}$ total (total of seven harvests) biomass yield, and $99.2-159.1 \mathrm{~kg} / \mathrm{ha}$ total essential oil yield per hectare. Application of FYM at 15 t/ha per year increased the total biomass yield by $10.7 \%$ and total essential oil yield by $10.3 \%$ over control (no application of FYM). Addition of nitrogen (N) at 80 $\mathrm{kg} / \mathrm{ha}$ per year enhanced the total biomass yield by $57.6 \%$ and total essential oil yield by $60.3 \%$ in comparison to no $\mathrm{N}$ application. The quality of the essential oil with 1.7\% (E)-â-ocimene, 2.5\% linalool, $73.1 \%$ geraniol, $15.8 \%$ geranyl acetate and $2.0 \%$ â-caryophyllene was found to be good and was readily accepted in the market. (B.R.Rajeswara Rao 2001)

Effect of phosphorus on herbage yield of Palmarosa: Chandra (1983) recorded a brief information on the requirement of phosphorus fertilizers for increasing the herb yield of following plants has been given Plantago ovata, Ranwolfia canescens, R. Serpertina, Atropa spp., Cassia angustifolia, Costus speciosus, Trigonella foenum graecum, Catheranthus roseus, Fagopyrum spp., Hyoscyamus niger, Pepaver somniferum, Digitalis spp., Cymbopogon nardus, Cymbopogon martinii var. Motia.

However significantly highest coriander plant height upto $51.68 \mathrm{~cm}$ was observed with the application of $40 \mathrm{~kg} \mathrm{P} \mathrm{O}_{5} \mathrm{ha}^{-1}$. ( Ghosh and Maity 1985). The application of $P$ at $60 \mathrm{~kg} \mathrm{P}_{2} \mathrm{O}_{5}$ ha-1 significantly increased dry matter $(28-31 \%)$ of Japnese mint over control. (Chuhan et al. 1991) Singh et al. (1991) obtained highest plant height tiller production at each cutting were increased with $\mathrm{P}$ levels upto $35 \mathrm{~kg} \mathrm{ha}^{-1}$ at high level nitrogen N $120 \mathrm{~kg}$ $\mathrm{ha}^{-1}$ in all cuttings in Citronella. At same level dry matter yield was 6.97 and 10.20 tha $^{-1}$ and citronella oil $211 \mathrm{~kg} \mathrm{ha}^{-1}$ and $380 \mathrm{~kg} \mathrm{ha}^{-1}$ in first and second year respectively.

A field experiment was conducted by Jayashree Bhaskar (1996) at Watershed Management Research Unit, A kola who investigated that plant growth of fennel in terms of height was significantly improved with application of $40 \mathrm{~kg} \mathrm{P}_{2} \mathrm{O}_{5}$ $\mathrm{ha}^{-1}$. The application of $20 \mathrm{~kg} \mathrm{P}_{2} \mathrm{O}_{5} \mathrm{ha}^{-1}$ produced significantly highest tillers plant ${ }^{-1}(17)$, plant height $(26 \mathrm{~cm})$ and plant spread $(14.5 \mathrm{~cm})$ over control in Isabgol crop. Nandi and Chatterjee (1997) studied that application of $60 \mathrm{~kg} \mathrm{~N}+50 \mathrm{~kg} \mathrm{P}+30 \mathrm{~kg} \mathrm{~K} \mathrm{ha-}$ ${ }^{1}$ gave the optimum, herbage, citronella oil and aldehyde content increased by $18.80,10.20$ and 4.00 per cent respectively over control. Sukhmal Chand and Rao (1996) carried out two field investigations on an alfic ustochrept soil under semi arid tropical climatic conditions revealed that $39 \mathrm{~kg} \mathrm{P}$ and $75 \mathrm{~kg}$ $\mathrm{K}$ ha applied in three equal splits at one split per harvest using point placement technique produced the tallest plants. Highest tillers plant ${ }^{-1}$, maximum dry herbage and essential oil yields of lemongrass without affecting essential oil content and citral percentage.

Jadhav et al. (2000) reported that application of phosphorus @ $20 \mathrm{~kg} \mathrm{ha}^{-1}$ to Isabgol crop produced significantly higher plant height $(32.49 \mathrm{~cm})$ and yield attributes viz., number of spikes plant $^{-1}(14.83)$, spike length $(2.92 \mathrm{~cm})$ over control. The application of $100 \mathrm{~kg} \mathrm{~N} / \mathrm{ha}$ with 40 each $P$ and $\mathrm{K} \mathrm{ha}^{-1}$ was gave higher return than control. It yield $20 \mathrm{t} \mathrm{ha}^{-1}$ of fresh herbage from rainfed crop, $30 \mathrm{t} / \mathrm{ha}$ from irrigated and produced $100 \mathrm{~kg}$ and $180 \mathrm{~kg}$ lemongrass oil yield ha-1 respectively (Anonymous, 2001).

Effect of nitrogen on NPK content and uptake of Palmarosa: The yield of herbage, essential oil and nitrogen uptake by the crops was increased with the increase in the rates of nitrogen from 0 to $80 \mathrm{~kg}$ 
$\mathrm{ha}^{-1} \mathrm{yr}^{-1}$. Maximum oil was produced at application of $80 \mathrm{~kg} \mathrm{~N}$ with $50 \mathrm{~kg} \mathrm{P}$ and $50 \mathrm{~kg} \mathrm{~K} / \mathrm{ha}$ in Citronella.( Ghosh and Chatterjee 1978) Prakasha Rao et al. (1983) conducted a two year experiment (1979-81) to study the effect of N, P and $K$ fertilizers on growth and yield of J ava citronella in a sandy loam soil. Application of $200 \mathrm{~kg} \mathrm{~N} \mathrm{ha}^{-1} \mathrm{yr}^{-1}$ resulted in significantly high yields of herb and essential oil and uptake of $\mathrm{N}, \mathrm{P}$ and $\mathrm{K}$. J ava citronella did not respond to $P$ and $K$. N recoveries by Citronella were found to be quite poor (about 20\%).

Prakasha Rao et al. (1985) observed that application of $\mathrm{N}$ fertilizers $100 \mathrm{~kg} \mathrm{~N} \mathrm{ha-1} \mathrm{yr}^{-1}$ increased the herbage and essential oil yield of $C$. flexuosus while $P$ and $K$ fertilizers did not show any increase. Lemongrass removed about $134 \mathrm{~kg} \mathrm{~N}, 28$ $\mathrm{kg} \mathrm{P}$ and $169 \mathrm{~kg} \mathrm{~K}$ in six harvest. $\mathrm{N}$ application (100 $\mathrm{kg} \mathrm{N} \mathrm{ha}^{-1} \mathrm{yr}^{-1}$ ) increased the uptake of N, P and $\mathrm{K}$ by lemon grass. The apparent recoveries of $\mathrm{N}$ by lemon grass varied between 29 per cent and 38 per cent. Yadav et al. (1984) studied the fertilizer nitrogen recovery and growth of J ava citronella as influenced by nitrogen and concluded that the herbage, citronella oil yields and nitrogen uptake by the crop increased with the increased rate of nitrogen from 0 to $180 \mathrm{~kg} \mathrm{ha}^{-1}$ in all cuttings. Total herbage production increased by 28.40 and $53 \%$ and Citronella oil by 26,38 and 49 to due 60,120 and $\mathrm{kg} \mathrm{N} \mathrm{ha}^{-1}$ respectively over control.

A field experiment was conducted on J ava citronella for two years during 1982-84 at the Central Institute of Medicinal and Aromatic Plants, Banglore and reported that application of $375 \mathrm{~kg} \mathrm{~N} \mathrm{ha}^{-1} \mathrm{yr}^{-1}$ resulted in the highest herbage yield and nitrogen uptake. The apparent $\mathrm{N}$ recoveries of J ava citronella were very low (ranging from 11 to $17 \%$ ). Application of nitrogen at six equal splits at two monthly intervals resulted significantly higher herb yield, $\mathrm{N}$ uptake and apparent $\mathrm{N}$ recovery in comparison with other times of $\mathrm{N}$ application.( Prakasha Rao 1988) Sundaravadivel et al. (2000) observed the effects of different $\mathrm{N}$ sources at different rates on the oil yield and soil fertility of Palmarosa (Cymbopogon martini) in Vertisols under rainfed conditions. The application of urea at $75 \mathrm{~kg} \mathrm{ha}^{-1}$ registered the highest herb yield (10606 kg ha-1) and oil yield (392 kg ha-1). The combined application of organic (FYM) and inorganic (Urea) fertilizers to supply $\mathrm{N}$ in equal proportions at $100 \mathrm{~kg} / \mathrm{ha}$ produced maximum oil recovery. Reduction in the herb yield was observed with the application of organic $N$ source. The application of $75 \mathrm{~kg} \mathrm{~N} \mathrm{ha}^{-1}$ produced highest levels of available nutrients ( $N, P$ and $K$ ) in the soil.

\section{Effect of phosphorus on NPK content and} uptake of Palmarosa: Barooh and Khader (1990) observed that addition of $40 \mathrm{~kg} \mathrm{P} \mathrm{ha}^{-1}$ in the soil, stimulates bio-synthesis of high energy phosphate compounds and the uptake was high on 45 days after application in presence of higher $\mathrm{N} \mathrm{(80}$ and $120 \mathrm{~kg} / \mathrm{ha}$ ) levels resulted to higher yield in Palmarosa grass. J amuna et al. (1991) reported that application of 40,60 and $80 \mathrm{~kg} \mathrm{P}_{2} \mathrm{O}_{5}$ ha-1 increased significantly highest phosphorus content progressively at flowering with increasing grain and bhusa yield of coriander. The application of $22 \mathrm{~kg} \mathrm{P}_{2} \mathrm{O}_{5} \mathrm{ha}^{-1}$ increased the $\mathrm{K}$ uptake (304.8 kg ha-1 $2 \mathrm{yrs}^{-1}$ ) through biomass yield of Palmarosa. (Rajeshwara Rao et al. 1991) Detroja et al. (1996) observed that with the application of $60 \mathrm{~kg}$ nitrogen ha-1 along with $120 \mathrm{~kg}$ phosphorus ha-1 in fenugreek the NPK uptake of seed as well as straw increased significantly. In Isabgol crop rapplication of $20 \mathrm{~kg} \mathrm{P}_{2} \mathrm{O}_{5}$ ha-1 $^{-1}$ recorded significantly higher $\mathrm{N}\left(14.60\right.$ and $\left.17.39 \mathrm{~kg} \mathrm{ha}^{-1}\right)$ and $\mathrm{P}_{2} \mathrm{O}_{5}(2.76$ and $1.69 \mathrm{~kg} \mathrm{ha}^{-1}$ ) uptake by grain and straw, respectively over lower levels of phosphorus ( adhav et al. 2000).

Aishwath et al. (2005) reported that application of $40 \mathrm{~kg} \mathrm{P}_{2} \mathrm{O}_{5} \mathrm{ha}^{-1}$ significantly increased P uptake (8.2 $\mathrm{kg} \mathrm{ha}^{-1}$ ) as compared to control during first year of experimentation of Isabgol. Field experiments were conducted at Research Farm of National Research Centre For Medicinal and Aromatic Plants, Boriavi (Anand), Gujrat during 1999-2000 and 2000-2001 studied that application of $40 \mathrm{~kg} \mathrm{P}_{2} \mathrm{O}_{5}$ ha-1 $^{-1}$ recorded significantly higher uptake of $\mathrm{N}\left(72.7 \mathrm{~kg} \mathrm{ha}^{-1}\right), \mathrm{P}\left(7.8 \mathrm{~kg} \mathrm{ha}^{-1}\right)$ and $\mathrm{K}$ (65.3 $\left.\mathrm{kg} \mathrm{ha}^{-1}\right)$ by Isabgol Crop.

Considering the importance of this crop yours are being made to increase the oil production of the crop by using improved nutrient management practices. Since, the encouraging results obtained may serves as a guidelines to the Palmarosa growers to adopt suitable technologies for higher yield. 
Vol. 34, No. 4, 2013

REFERENCES

Aishwath, O. P., Ram Chandra, Dinesh Kumar and J ha. B. K. (2005). Yield and macronutrient uptake by Isabgol (Plantago ovata) with application of N and P under medium soil fertility. Indian J . Soc. Soil Sci. 53: 410-412. Anonymous. (2001). Hand Book of Horticulture, ICAR, New Delhi pp 614-624.

Barooh, M., Khader. M. D. (1990). Studies on phosphorus utilization by Palmarosa (Cymgopogon martinii var. Motia). Indian Perfumer. 34: 147-151.

Chandra, V. (1983). N utrient requirements for some medicinal and aromatic plants. Biol. Mem. 6(1) : 81-96.

Chuhan, H. S., Ram, P. Singh U. V. and Singh K. (1991). Response of J apnese mint (Mentha arvensis L.) to phosphorus and zinc on mollisoles of Tarai belt in Uttar Pradesh. Indian Perfumer. 35: 150-15

Chatterjee, S. K. and G hosh. M. L. (1973). Cultivation of essential oil yielding plants in the hilly tracts and Gangetic plains of West Bengal. Indian Perfum. 17: 31-34.

Detroja, H. J ., Sukhadia, N. M. Khanpara, V. D. Malavia D. D. and Kaneria B. B. (1996). Response of fenugreek (Trigonella foenum Graecum) to nitrogen, phosphorus and potassium. Indian J. Agron. 41: 179-180.

Dutta, P. K. and Paul. S. C. (1976). Effect of fertilizers on the herb yield and oil content of Palmarosa grass (Cymbopogon martinii Var. Motia). Medicinal and Aromatic Plants. GAU Anand. pp 112.

Ghosh and Maity. (1985). Effect of nitrogen and phosphorus on growth and yield of coriander. Indian Coco, Arecanut and Species J . 9(2) : 44-46.

Ghosh, M. L. and Chatterjee S. K. (1978). growth and essential oil content of J ava citronella in Burdwan West Bengal. Indian Perfumer. 22(4): 964-968.

Hazarika, J. N., Baura, A. Barua A. K. A. (1978). Effect of NPK fertilizers on the yield and quality of Palmarosa (Cymbopogon martinii Var. Motia) under the influence of seasonal variations. Indian Perfum. 22: 36-39.

Hazarika, J. N. and Bora. A. C. (1977). Effect of varying combinations of NPK fertilizers on yield of Palmarosa (Cymbopogon martinii Var. Motia). Indian Perfum. 31: 51-53.

Husain A khtar. (1979). Development of a high yielding variety of citronella adopted to north Indian. Plains annual report CIMAP Lucknow. pp 9.

J adhav, C. N., Sukhadia N. M. and Ramani B. B. (2000). Effect of sowing dates, nitrogen and phosphorus on growth and yield of Isabgol (Plantago ovata Forsk). GAU. Res. J. 25: 84-87.

J amuna, P. P., Rao, N. Reddy P. V. Rao M. R. (1991). Phosphorus requirement of coriander in black clay soil of low available $\mathrm{P}_{2} \mathrm{O}_{5}$. Indian Cocoa, Arcanut and Species] ournal. 14: 112-113.

J ayshree B haskar, Bharad G. M. and Patil S. N. (1996). Effect of plant population, nitrogen and phosphorus on grain Amarnath (Amaranthus species). Indian J. Agron. 41:

Nair, E. V. G., Chinnamma, N. P. Kumari P. K. (1979). A quarter century of research on lemongrass at LRS. Indian Perfum. 23: 218-219.

Nandi, R. P. and Chatterjee S. K. (1997). Improved cultivation and distillation method followed by citronella plantation of Darjeeling H ills. Indian Perfumer. 35: 24-29.

Prakasha Rao, E. V. S., Narayana M. R., Munnu Singh and Puttanna. (1983). Effect of N, P and K fertilizer on growth yield and nutrient uptake in J ava citronella (Cymbopogon winterianus] owitt). Z. Ackerp Flazerb. 152: 279-293.

Prakasha Rao, E. V. S., Narayana M. R., Munnu Singh, Puttanna. (1985). Effect of NPK fertilizers on growth yield and nutrient uptakes in J ava citronella (Cymbopogon winterianus J owitt). Z. Ackerp Flazerb. 15: 279-283.

Prakasha Rao, E. V. S., Singh M. and Chandrasekhar G . (1988). Effect of nitrogen application on herb yield nitrogen uptake and nitrogen recovery in J ava citronella (Cymbopogon winterianusJ owitt). Indian J . Agron. 33: 412-415.

Rajan, K. C., N. Sadanandan and E. V. G. Nair. 1984. Aromatic and medicinal plants research station Asamannoor. 683-549 Odakkali, Kerala. Agric. Res. J. Kerala. 22: 37-42.

Rajeshwara Rao, B. R., Prakasa Rao E. V. S., Singh K. and Singh M., Kaul P. N. and Bhattacharya A. K. (1991). Fertilizer effect on Palmarosa (Cymbopogon martinii) under semi-arid tropical conditions of India. Indian J . Agric. Sci. 61: 169-174.

Rajeswara Rao ,B.R (2001).Biomass and essential oil yields of rainfed palmaros(Cymbopogonmartinii Roxb.) Wats. var. motia Burk.) supplied with different levels of organic manure and fertilizer nitrogen in semi-arid tropical climate. Industrial Crops and Products.14:171-178

Singh, K., Chowdary A., Subrahmanyam K., Chatterjee B. N. and Singh D. V. (1991). G rowth and yield response of citronella J ava (Cymbopogon winterianus J owitt) to phosphorus and potassium levels at high nitrogen. J . Potassium Res. 7: 35-46.

Sukhmal Chand and Rajeswararao B. R. (1996). Response of lemongrass to levels and methods of application of phosphorus and potassium. J ournal of Potassium Research. 12: 400-405

Sundaravadivel, K., Chitdeswari T., Periswamy M., Subrahamanian M. and Krishnadas D. (2000). Nitrogen levels and sources on herb oil yield and soil fertility of rainfed Palmarosa. Madras Agric. J . 86: 272-274.

Virmani, O. P., K. Singh and R. P. Singh. (1979). Citronella and its cultivation in India CIMAP, Lucknow. Farm Bull No. $1: 6$.

Yadav, R. L., M. Anwar and M. Ram. (1984). Fertilizers nitrogen recovery and growth of java citronella as influenced by row spacing and nitrogen. Indian J . Agron. 29:305-308. 